DOI https://doi.org/10.18551/rjoas.2017-11.26

\title{
THE INFLUENCE OF SEXUAL VIOLENCE CODE EXPOSURE TOWARD PARENTS' COGNITION ROUTES
}

\author{
Rahmiati Dyan*, Hermawan Faizah, Kusumawanti Nike \\ University of Brawijaya, Indonesia \\ *E-mail: dyanrahmi@gmail.com
}

\begin{abstract}
Messages and sign have certain influence toward humans' cognition, yet different person might perceive them differently. Persuasive message appears to be one type of messages which has the strongest potential in modifying ones' behavior. Children and anything about them are parents' biggest proximity. Regarding to the massive exposure of sexual violence cases happened to children, parents demand access to know more information on this issue. This research is intended to see the effect of the exposure on news about sexual violence in children toward cognition route of parents who have daughters, and to see if there is any different cognition route between fathers and mothers in perceiving news related to sexual violence on children. This research employed an experimental method using the one group pre-post test design. This research involved 15 parents who have daughters who were chosen using an accidental sampling method. This reseach was conducted in the computer laboratory of FISIP UB. Sexual violence codes were displayed in some videos which showed some news on sexual violence happened to children. After that, an instrument in the form of central code and peripheral cognition route scale which was developed from the elaboration likegood model (ELM) was given to the samples in the form of questionnaires after they watched some persuasive messages. The results of the data were analyzed using t-test of SPSS 22.0 program. The result of this reseach shows that there is an effect of sexual violence news toward parents' congition route at 0.820 in a level of significance 0.000 , while the congiton route of mothers shows higher mean value at 104.66 than fathers at 91.73 .
\end{abstract}

\section{KEY WORDS}

Code message exposure, sexual violence, cognition route, parents.

Women and children are stigmatized to be the weak group among the society in Indonesia. It can be seen from the presence of the protection of women and children and other non-government organizations that focus on this issue. Domestic violence is often blown up on the media, highlighting on the poor condition of women and children as the victims. Moreover, mass media also put spotlight on the news of sexual violence happen to children in some parts of Indonesia. According to the national commission of women and children, case of domestic violence tends to increase in these past years. In 2015, as many as 321.752 case of domestic violence were recorded which is significantly higher than the number of domestic violence in the previous year 232.220 cases (MAP Corner-Klub MKP UGM, 2016). Jacob Oetama (Perpektif Pers Indonesia) stated that "news is not a fact, but it is a report of a fact". Thus, the high requence of news on sexual violence to children reflects the real condition in the society. Even more, the condition is rather like an ice berg phenomena, in which the cases exposed by the media are merely a small part of the real condition in the field (Fauziah, Luluk - Pusat Pelayanan Terpadu Pemberdayaan Perempuan dan Anak (P2TP2A) Sidoarjo - 2015).

The frequent news on the matter has a high proximity for parents since parents hold the duty to protect their family. Hence, news about sexual violence happened to children can be classified as persuasive news for parents, especially those who have daughters. Persuassive news has certain effect on humans' behavior. Based on the theory on the Elaboration Likehood Model (ELM), the effect is caused different cognition among individuals in perceiving certain messages. 
ELM provides a general framework as a guide to manage, classify and understand the basic process of an effective persuasive communication. There are two different routes of a persuation (Petty, 1977; Petty \& Cacioppo, 1978). The first route is obtained by individuals who are very careful and considerate in filtering certain information given to them (central route). The second one is obtained as the result of perceiving signs and other attractive persuasion with less detail in analyzing the real fact (peripheral route). ELM is often applied in psychotherapy and counseling model (Cacioppo, Petty \& Stoltenberg, 1985; Petty, Cacioppo \& Heesacker, 1984) and in creating advertisement to increase sales (Cacioppo, Petty, 1985; Petty \&Cacioppo, 1983a, 1984b; Petty, Cacioppo \& Schumann, 1984), besides it is also used in political acts or communication attemps by politicians.

Socio-psychologic trandition has resulted a review on communobiology field which according to Littlejohn \& Foss (2009, h.964) consists of three big brances which are: behavior, cognition, and biological domain. The term communobiology refers to a study on communication seen from biology point of view (Littlejohn dan Foss, 2009, h. 65).

Different social construction between men and women has raised a view that men tend to think rationally, while women are rather irrational in perceiving certain reality. The psychological condition of women that creates emotional behavior and thoughts was used as the starting point to begin this research in comparing the cognition routes between men and women in perceiving persuasive news with strong proximity related to their role as parents of their daughters. This research also intended at analyzing the effect of frequent news on sexual violence happened to children toward their cognition routes. In addition, this research was also done to find out if there were any differences on cognition routes of fathers and mothers in perceiving the news.

\section{LITERATURE REVIEW}

Message codes and cognition route. Elaboration Likehood Model is a theory that focuses on the change of human behavior triggered by the use of cognition route in receiving stimulus in the form of message. Different cognition routes lead to different effects of a certain persuasive message; either it leaves temporary effect or permanent effect.

“... ELM (Petty \& Cacioppo; 1981a) which believe provides a fairly general framework for organizing, categorizing, and understanding the basic process underliying the effectiveness persuasive communication" (Richard E. Petty and John T Cacioppo; 1986 125).

Persuasive attempts that generate permanent effect are better than the ones that leave temporary effects. Previous reseach have shown a proposition that permanent effects are obtained out of ones' ability to think critically and rationally.

This theory is commonly applied in psychotheraphy and counseling (Cacioppo, Petty \& Stoltenberg, 1985; Petty, Cacioppo \& Heesacker, 1984), and in designing advertisement and sales (Cacioppo \& Petty, 1985; Bitner. May J. \& Obermiler. Carl, 1985; Petty \& Cacioppo, 1983a, 1984b; Petty, Cacioppo \& Schuman, 1984). This theory was also used in medical field to generate effective communication in heath promotion for behavior modification by Richard E Peety, Jamie Barden and Christian Wheeler. Especially within the interrelationship of congition routes, comprehension on messages and behavior change (Helweg. Larsen dan Collins, 1997; McNair, 1991) are the indicators to describe the strength of certain behavior such as self-esteem which needs to be measured (Petty and Krosnic, 1995).

ELM is a general framework to manage, classify, and understand the basic process in creating high effectiveness of a persuasive communication. There are two different routes of a persuasion persuasi (petty, 1977; petty \& Cacioppo, 1978). The two routes deal with the cognitive process in perceiving certain message (Petty dan Cacioppo ,1986, h. 131). It has been known that by enhancing motivation, the central route puts more emphasize on the argumentation of certain problem, while peripheral route works when the ability is limited and the behavior is likely influenced by positive or negative signs within a persuasive context. Those two routes are directly associated with where the message is stored and how ones create simple conclusion to measure the validity of a message. 


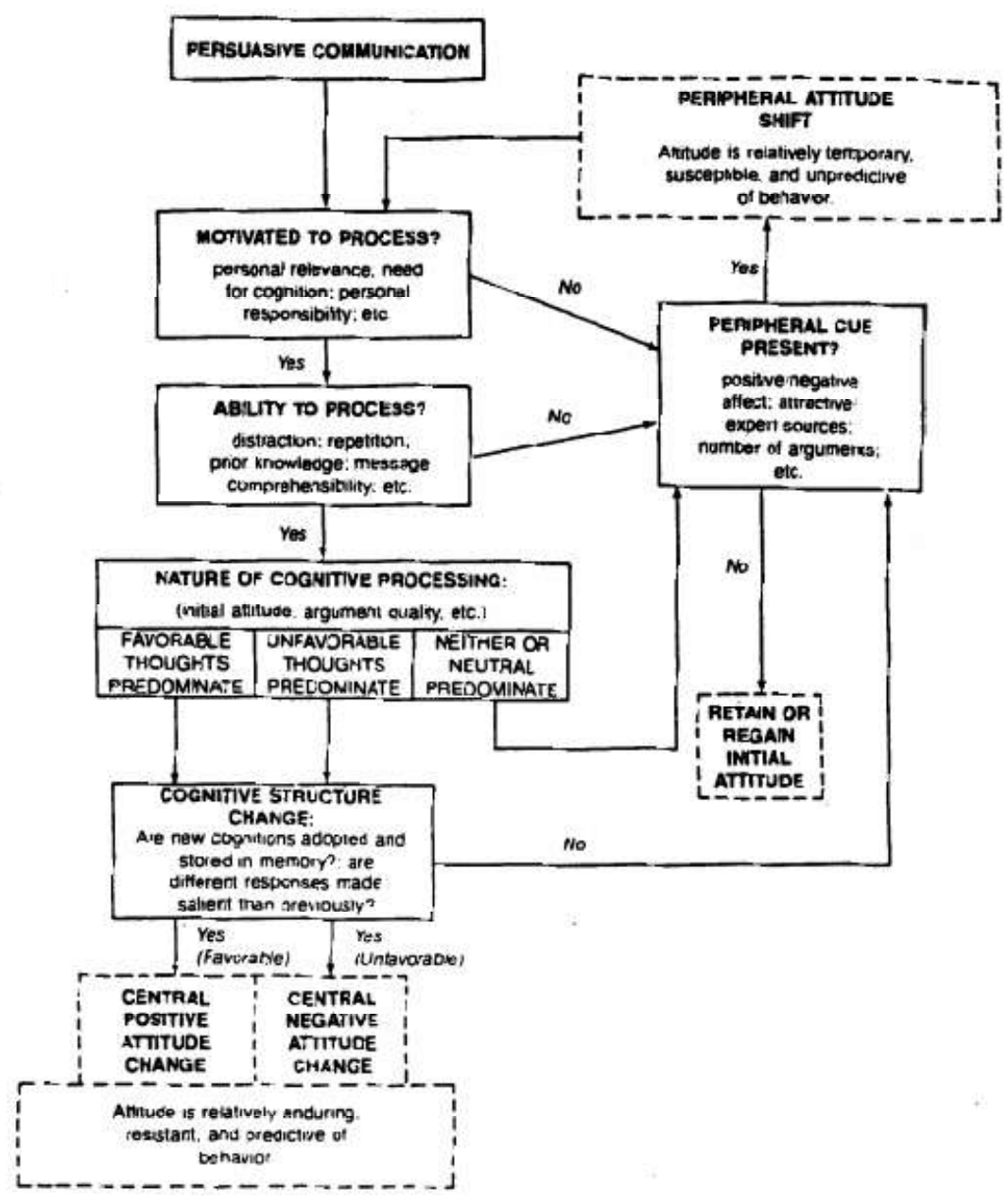

Figure 1 - Central and peripheral routes to persuasion (adapted from Petty, 1977; Petty \& Cacioppo, 1978, 1981a)

There are three variables that influence the strength and the orientation of human behavior which are: (a) the presence of persuasive argument, (b) the presentation of a message as a peripheral sign (c) the expansion of the scope and the orientation of the argument. Based on the result of previous research, simple and easy-to-understand message appears to be the strongest factor that determines the effectiveness of a persuasive argument. Peripheral signs are affectively influential and it is later associeated with the behavioral objects. Similar to compelling and impelling acts which are believed to contain peripheral signs, rules and inferences are also considered as kinds of peripheral signs (h. 134). A research on information processing has a strong correlation with verbal stimulus and focus of central processing upon the content of a message (Rader, 1994 h.1). other variables that are frequently used in designing an advertisement are colors, shapes, motions, sounds, visualization, images and music. Musical arrangement also influences information processing through awareness, attention, distraction and retrieval (Alpert \& Alpert, 1990; Scott, 1990).

Study on message codes embraces three major topics including (1) source cue studies, (2) message cue studies, (3) aditional cue studies which each has its own condition. Meanwhile, peripheral factors which are often used as to explain behavior change are: (1) social evidence, (2) benefits gained, (3) scarcity, (4) persuaders' credibility, (5) returning the favor, and (6) authority (Griffin 2003, West and Turner 2008, O' Keefe 1990, Larson 2006). In this research, the researchers employed message cue and additional cue without using the source cue. 
Parents and gender stereotyping. Among adults, generally they perceive parenting as a duty that should be well-planned and it should be coordinated with other roles, besides it is also expected to develop according to individuals' economic state. In a family, parents have a major influence to the children since children spend most of their time at home. Parents hold the duty to educate their children. In this context, generally, parents are also responsible in maintaining their children physical health by providing good food and good life. Parents always try to give attention and affection to their children which attention comes out of centralization or concentration of individuals' activity directed at an object or at some objects. Attention can be seen from (Walgito, 2010): (1) the source of attention; (2) the number of object covered by an attention within a certain period of time; (3) the scope of the attention; (4) the fluctuation of the attention.

Identifying the role of gender should start by defining the term gender itself. The term gender is also associated with sex (Echols and Hassan Shadily, 1995). Gender is a sociocultural and psychological dimension of women and men, while sex refers to the biological dimension owned by men and women. The role of gender as stated by Wilson in Khanafi, in a broader scope "gender is a basis for beginning the different contributions that man and woman make to culture and collective life by distinction which they are as man and woman." (Wilson, 1989: 2).

The strong socialization has shaped a gender ideology through organizational social construction (Fakih, 2008). Women are constructed as creatures who are in need of protection, dependant, irrational, emotional, and so on. The concept of this gender has created differentiation in the role of gender within a family which puts the women or wives to hold their role within a narrow domestic scope to take care of households. Whereas, men are put in public scope to make living. Gender stereotyping also covers broader scope which reflects ones' belief on appropriate behavior that should be shown by women and men (Santrock, tt: 197) including the role differentiation in taking care of children.

Research Hypothesis

$\mathrm{H}_{1}$ : there is an effect of sexual violence code message exposure toward parents' cognition routes;

$H_{0}$ : there is no effect sexual violence code message exposure toward parents' cognition routes.

\section{METHODS OF RESEARCH}

The researchers were interested in knowing if there was any effect of news on sexual violence happened to children toward the congition routes of fathers and mothers. This research was done under the quantitative approach using experimental method. Experiment method was used, in which the researchers gave certain treatment or manipulation on one or more variables in a certain way that it influences other treatment in the measurement (Michael, 1977: 24). Variable refers to a concept that has variation of values. The idenfitication of variables in this research were: independent variable $(X)$ : Sexual Violence News; and dependent variable (Y): Cognition Route.

Operational Definition:

Code message is a factor that influences the degree of behavior change related to sexual violence including (a) the presence of persuasive argumentation, (b) the presentation as peripheral signs, (c) the ability to expand the scope and direction of an issue and the explanation on the argumentation.

Cognition route is the path taken to cognitively process a message whch includes (Petty and Cacioppo ,1986, h. 131):

- Central route -Central route is used when an individual has high motivation and ability to understand the argumentation of a certain issue.

- Pherpheral route - Peripheral route is used when an individual has relatively low ability and whose behavior is highly influence by either positive or negative signs of a persuasion which are later associated with the position of the message or by using simple conclusion as a validity measurement. 
The population of this research included male parents (fathers) and female parents (mothers) who had daughters. Out of the population, 15 fathers and 15 mothers whose daughter were teenagers were chosen as the sample of this study. Accidental sampling technique was used to pick the samples.

Questionnaires were distributed twice, before and after the treatment. Besides questionnaires, the researchers also employed a visual instrument in the form of video that contained various news on sexual violence happened to children. This research took place in the computer laboratory which had been modified to fit the need of this research such as modifying the available devices, and procedures in filling up the scales when they were exposed with news on sexual violence happened to children.

The procedure of this research was divided into three parts: 1) research planning, 2) research implementation, 3) data analysis. In the research planning, operational actions done in this step included: a) designing code message in the form of informational videos on sexual harassmen happened to children. Questionnaires on the cognition route were also created (attached), b) preparing the tools and intruments in conducting the research, and rechecking the data of the research subjects, c) designing the experimental treatment.

The implementation of the research was initiated by conducting the pretest, followed by giving treatment to the experimental group. The treatment was done by showing the subjects videos that contained certain code messages on sexual violence happened to children. The treatment took place in the computer laboratory, and lastly, the subjects were given questionnaires to answer related to cognition route.

Lastly, the obtained data were analyzed using the t-test of SPSS application version

Experimental Design. Experimental research method was employed in this study using one group pretest-posttest design. In the early stage of the research, the dependent variable was measured using pretest. After being manipulated through certain treatment, the variable was then re-measured using the same instrument (Christensen, in Seniati, Yulianto, Setiadi, 2005).

The experimental design used in this study is presented in Table 1.

Table 1 - Experimental Design

Measurement (01)

Manipulation (X)
Measurement (O2)

Notes: 01 - Measurement before the manipulation; X-Manipulation; O2 - Measurement after the manipulation.

\section{RESULTS AND DISCUSSION}

The obtained data on the effect of code message about sexual violence toward parents' cognition routes. The results of the data analysis indicate the influence of code message on sexual violence exposure to the parents toward their cognition route at a level of significance 0.000 . The result of the measurement is shown in Table 2.

Table 2 - Average score of pretest and posttest

\begin{tabular}{|c|c|c|c|c|c|}
\hline \multicolumn{2}{|c|}{$\mathrm{n} / \mathrm{n}$} & Mean & $\mathrm{N}$ & Std. Deviation & Std. Error Mean \\
\hline \multirow{2}{*}{ Pair 1 } & pretest & 95.7667 & 30 & 7.52322 & 1.37355 \\
\cline { 2 - 5 } & posttest & 98.2000 & 30 & 9.28254 & 1.69475 \\
\hline
\end{tabular}

The data show that there is a significant improvement in the mean value from 95.76 to 98.20 which implies that there is a change on the congition routes taken by the parents after watching the video containing code message on sexual violence happened to female children.

Table 3 - Correlational value and significance

\begin{tabular}{|c|c|c|c|c|}
\hline \multicolumn{2}{|c|}{$\mathrm{n} / \mathrm{n}$} & $\mathrm{N}$ & Correlation & Sig. \\
\hline Pair 1 & pretest \& posttest & 30 & .820 & .000 \\
\hline
\end{tabular}


The obtained values show a strong and positive correlation between the two variables at a correlational value of 0.820 at the level of significance 0.000 . Thus, it is confirmed that there is an effect of code message about sexual violence happened to children toward parents' cognition routes.

Table 4 - Result of the t-test

\begin{tabular}{|c|c|c|c|c|c|c|c|c|c|}
\hline \multirow{3}{*}{\multicolumn{2}{|c|}{$n / n$}} & \multicolumn{5}{|c|}{ Paired Differences } & \multirow{3}{*}{$\mathrm{t}$} & \multirow{3}{*}{ df } & \multirow{3}{*}{$\begin{array}{c}\text { Sig. } \\
\text { (2-tailed) }\end{array}$} \\
\hline & & \multirow[t]{2}{*}{ Mean } & \multirow[t]{2}{*}{ Std. Deviation } & \multirow{2}{*}{$\begin{array}{l}\text { Std. Error } \\
\text { Mean }\end{array}$} & \multicolumn{2}{|c|}{$\begin{array}{l}\text { 95\% Confidence Interval } \\
\text { of the Difference }\end{array}$} & & & \\
\hline & & & & & Lower & Upper & & & \\
\hline Pair 1 & $\begin{array}{l}\text { pretest - } \\
\text { posttest }\end{array}$ & -2.43333 & 5.31545 & .97046 & -4.41816 & -.44851 & -2.507 & 29 & .018 \\
\hline
\end{tabular}

The $t$-value is found at -2.507 at the level of significance 0.018 which points out that there is a gap between the condition before the treatment and after the treatment.

The differences of cognition routes between fathers and mothers. The result of this reseach shwos that the cognition route taken by mothers is significantly higher than the route taken by fathers. The data is presented in Table 5.

Table 5 - Average score of cognition routes based on sex

\begin{tabular}{|c|c|c|c|c|c|}
\hline & Sex & $\mathrm{N}$ & Mean & Std. Deviation & Std. Error Mean \\
\hline \multirow{2}{*}{ Cognition route } & 1.00 & 15 & 104.6667 & 6.51007 & 1.68089 \\
\cline { 2 - 6 } & 2.00 & 15 & 91.7333 & 6.81874 & 1.76059 \\
\hline
\end{tabular}

Notes: sex 1 = female; sex 2 = male.

The mean score of cognition route in female parents is 104.66 which is higher than the mean score obtained by fathers at 91.73. It implies that mothers have higher awareness toward the matter which can be seen from the detailed information presented by the central and peripheral routes compared to fathers.

Table 6 - Result of the t-test

\begin{tabular}{|c|c|c|c|c|c|c|c|c|c|c|}
\hline \multicolumn{11}{|c|}{ Independent Samples Test } \\
\hline & \multirow{3}{*}{$\mathrm{n} / \mathrm{n}$} & \multicolumn{2}{|c|}{$\begin{array}{l}\text { Levene's Test for } \\
\text { Equality of } \\
\text { Variances }\end{array}$} & \multicolumn{7}{|c|}{ t-test for Equality of Means } \\
\hline & & \multirow[t]{2}{*}{$\mathrm{F}$} & \multirow[t]{2}{*}{ Sig. } & \multirow[t]{2}{*}{$\mathrm{t}$} & \multirow[t]{2}{*}{ df } & \multirow[t]{2}{*}{$\begin{array}{l}\text { Sig. (2- } \\
\text { tailed) }\end{array}$} & \multirow{2}{*}{$\begin{array}{l}\text { Mean } \\
\text { Differe } \\
\text { nce }\end{array}$} & \multirow{2}{*}{$\begin{array}{l}\text { Std. } \\
\text { Error } \\
\text { Differe } \\
\text { nce }\end{array}$} & \multicolumn{2}{|c|}{$\begin{array}{l}95 \% \text { Confidence } \\
\text { Interval of the } \\
\text { Difference }\end{array}$} \\
\hline & & & & & & & & & Lower & Upper \\
\hline \multirow{2}{*}{$\begin{array}{l}\text { rutek } \\
\text { ognisi }\end{array}$} & $\begin{array}{c}\text { Equal } \\
\text { variances } \\
\text { assumed }\end{array}$ & .010 & .922 & $\begin{array}{c}5.31 \\
3\end{array}$ & 28 & .000 & $\begin{array}{c}12.933 \\
33\end{array}$ & $\begin{array}{c}2.4341 \\
5\end{array}$ & $\begin{array}{c}7.9472 \\
1\end{array}$ & $\begin{array}{c}17.919 \\
46\end{array}$ \\
\hline & $\begin{array}{l}\text { Equal } \\
\text { variances not } \\
\text { assumed }\end{array}$ & & & $\begin{array}{c}5.31 \\
3\end{array}$ & $\begin{array}{c}27.9 \\
40\end{array}$ & .000 & $\begin{array}{c}12.933 \\
33\end{array}$ & $\begin{array}{c}2.4341 \\
5\end{array}$ & $\begin{array}{c}7.9467 \\
2\end{array}$ & $\begin{array}{c}17.919 \\
94\end{array}$ \\
\hline
\end{tabular}

The t-value at 5.313 at the level of significance 0.000 shows that there is a difference between the cognition routes taken by mothers and fathers.

Table 7 - Cognition route of fathers

\begin{tabular}{|c|c|c|c|c|}
\hline $\mathrm{n} / \mathrm{n}$ & $\mathrm{N}$ & Mean & Std. Deviation & Std. Error Mean \\
\hline Male central & 15 & 57.8667 & 4.95504 & 1.27938 \\
\hline Male peripheral & 15 & 33.8667 & 3.56304 & .91997 \\
\hline
\end{tabular}

The mean score shows that fathers tend to activate the central cognition route more than the peripheral route at the central value of 57.86 and the peripheral value of 33.86 . 
Table 8 - Cognition route in mothers

\begin{tabular}{|c|c|c|c|c|}
\hline $\mathrm{n} / \mathrm{n}$ & $\mathrm{N}$ & Mean & Std. Deviation & Std. Error Mean \\
\hline central & 15 & 64.8000 & 3.82099 & .98658 \\
\hline pheriperal & 15 & 39.8667 & 4.08598 & 1.05500 \\
\hline
\end{tabular}

The mean scores show that mothers tend to use central cognition route more often than the peripheral cognition route. The mean of central cognition route is 64.80 , while the peripheral cognition route shows mean score 39.86 . The high value of the central cognition route shows the ability of mothers in rationalizing the content.

Code message about sexual violence happened to children is a persuasive message which is able to influence the parents to internalize the message. Within the context of ELM, the strength of the persuasion depends on the content that is being processed which is highly influenced by motivation, opportunity and ability to process the persuasive message (Purbawaningsih, 2012:4). The higher ones' motivation and ability in processing persuasive messages, the higher the tendency to take the central cognition route, and the vice versa (Cacioppo \& Petty, 1981). The message about sexual violence happened to children has been strong enough in growing parents' motivation in understanding and processing the content.

The development of persuasion model as explained in The Social Psychological Approach (2002: 203) includes: (1) change of behavior as the result of the persuasion through some steps (2) persuasion includes congitoin or information processing; (3) persuasion emphasizes on the active role of the persuade as the information-processing agent.

The theory of Elaboration Likehood Model also identifies two routes that are generally used in processing persuasive messages namely cerntral route and peripheral rotue. The difference between those two routes relies on the persuasion effect, behavior change, and any other changes (Dainton, 2010:109). People who need more adequate cognition tend to use the central route and they evaluate the message only from its function. Whereas, using the peripheral route, ones process information by associating the message with other information around it (Payne, 2005).

There is an obvious different between how mothers and fathers use their cognition route. Mothers show greater average value on the use of central cognition compared to fathers. The use of this central cognition route is indicated by the information processing which puts stronger consideration on the quality of the message or content, involving various knowledge and experience in evaluating the message and critically analyzing any information. Men's tendency in using central route more than other routes was also highlighted by Rizkana and Perbawaningsih in their unpublished thesis.

The level of involvement shows how someone become motivated to deeply think abot persuasive messages they receive (Rader, 1994. p.3). In the other words, the higher someone's involvement, the more systematic his/her thought through peripheral approach. Petty and Caciopo's (1981) stated that if the involvement is high, the central processing becomes more obviously seen, yet when the involvement is low, the peripheral processing appears more clearly.

Different from ELM, Chaiken's assumption identifies the role of peripheral codes such as music in influencing those who show high involvement (Rader, 1994. p.4). Literature information processing displays the non-verbal element (NVE's) which is as high as the verbal element. There is no certain differences between the verbal and non-verbal element which have specific relationship with the components of information. This research also has successfully identified that both fathers and mothers own lower level of peripheral route compared to the central route. Seen from the theory of ELM, parents have strong motivation to critically process any persuasive messages without thinking too much about peripheral codes.

Non-verbal components are often considered emotional and contain less informational (Edell, 1988) which make them often employed to attract certain audiences who tend to communicate using feeling and emotion. In this context, women tend to use feeling and 
emotion in processing certain information. Verbal and non-verbal communication may simultaneously appear in the form of gesture, facial expression and body language. They can also appear in the form of social and physical signs, environmental structure, other symbols such as colors, sounds and figures (Rader, 1994. h.7). Ones rather use the peripheral route when the message is out of the content and it contains information beyond the message in the form of colors, pictures, music, figures, photographs, and so on.

Fishbein and Ajzen (1981) stated that neglecting information in a message is the main problem in the reseach on communication and persuasion (Petty \& Cacioppo, 1986 p. 133). The mean score of the cognition route in mothers is significantly higher than the one of the fathers which implies that mothers have stronger attention to the details of an information using the central processing, while fathers are likely to use the peripheral processing. Ones will not perceive a phenomena as a whole phenomena, instead they create some options which are highly influenced by the attention, interest, and focus. Each person has certain differences in the number of code message received, interest, and involvement which enhance the motivation to give extra information on the given information. Mothers are likely to have higher motivation in receiving more detailed code message compared to fathers.

Personal relevance of a certain issue also influences the strength of a persuasive message for a person. Petty highlighted that ELM divides a message into to categories; strong and weak. The strength is affected by some factors including: disturbance, repetition, involvement and cognition necessity (Petty \& Cacioppo, 1996 p.144). The degree of involvement enhances the motivation, enabling a person to critically elaborate the content of a message. Personal relevance is labelled as 'ego-involvement' (Rhine \& Severance, 1970; Sherif \& Nebergall, 1965), "issue involvement" (Kiesler, Collins \& Miller, 1969), "personal involvement' (Apselrs \& Sears, 1968; Sherif, Kelly, Rodgers, Srup \& Tittler, 1973) and so on.

A person might have a hidden interest toward an issue that is being displayed or have certain personal insights on the matter. Personal relevance rises when a person owns an expectation that the issues have certain significant effects in life. The word 'significant' itself covers some dimensions such as the degree to which personal insights affect the isssues, the consequences and the length of the consequences. Specifically, the higher the personal relevance, the more motivated a person in processing the relevant issues by providing good argumentation (Petty \& Cacioppo, 1996 p.146).

Personal responsibility toward a certain issue makes a person give more effort in evaluating any relevant arguments that are being presented. 'Need for cognition' is a need to structure relevant situations in meaningful, integrated ways. It is a need to understand and make reasonable the experiential world (Cohen, Stotland and Wolfe, 1955 in Petty \& Cacioppo, 1996 p.151). A person who is in need of knowledge would do more effort in satisfying the curiosity by actively collecting information on the matter.

\section{CONCLUSION}

The exposure of code message on sexual violence happened in children affects parents' cognition route with the t-value of 0.820 at the significance level of 0.000 . Thus, the alternative hypothesis of this study is accepted in which the code message has been perceived as a persuasive message. This condition is influenced by the high personal relevance of the parents both mothers and fathers toward the issue about sexual violence happened in children. The result of this study shows that parents tend to activate the central cognition route rather than the peripheral cognition route. There is an obvious difference between the cognition route taken by mothers and the fathers at a level of significance 0.000 . The mean score obtained by the mothers was 104.66 which are higher than the score obtained by the fathers at 91.73 . Therefore, it can be implied that mothers tend to investigate the code message in a more detailed way and they tend to collect more information on the matter compared to fathers. Mothers have their both central and peripheral cognition routes more active than fathers. Gender difference does not have any significant effect to the use of cognition route in processing the code message on sexual violence happened to children. 


\section{REFERENCES}

1. Dani Alia. (2012). Perbedaan sikap ayah dan ibu terhadap kekerasan oleh guru. artikel.

2. Fakih, Mansour. (1998). Analisis gender da transformasi sosial, Yogjakarta:Pustaka Pelajar

3. Griffin, Em. 2003. A First Look at Communication Theory. New York: McGraw Hill Higher Education.

4. Littlejohn, Stephen W and Foss, Karen A. 2005. Theories of Human Communication. Eight Edition. California: Thomson.

5. Larson, Charles U. 1996. Persuasion Reception and Responsibility. California: Wadsworth Publishing Company.

6. McCroskey, James and Beatty, Michael J. (2000) The Communibiological Perspective: Implications for Communication in Instruction. Communication Education, Vol. 49, No. 1, January 2000: 1-6

7. Perwaningsih, Yudi. 1012. Menyoal Elaboration Likehood Model dan Teori Retorika. Volime 9 no. 1 h. 1-17. Jurnal Ilmu Komunikasi UAJY. Diakses dari: http://ojs.uajy.ac.id/index.php/jik/article/view/50

8. Petty, R. E. and Wegener, D. T. (1998) Attitude change: multiple roles for persuasion variables. In D. Gilbert and S. Fiske (eds) The Handbook of Social Psychology (Vol. 1, 4th ed.) 323-390. New York, NY: McGraw-Hill.

9. Petty, R. E. and Cacioppo, J. T. (1986) The elaboration likelihood model of persuasion. Advances in Experimental Social Psychology 19: 123-205.

10. Papalia, D.E, Olds, S. W, \& Fieldman, R.D. (2009). Human Development: Perkembangan Manusia. Jakarta: Salemba

11. Payne, Collin Richards (2005) The Elaboration likehod model of persuation: Implication for trial advocacy. The International Journal of Speech, language and the Law (IJSLL vol. 14.2, 2007) 309-312

12. Soetjiningsih. (2004). Tumbuh Kembang Remaja dan permasalahannya. Jakarta: CV. Sagung Seto

13. Sarwono, S. W. (2011). Psikologi Remaja. Jakarta: PT Rajagrafindo Persada

14. Seniati, L. Yulianto, A. Setiadi, B. (2005). Psikologi Eksperimen. Jakarta: Indeks.

15. Walgito, B. (2010). Pengantar Psikologi Umum. Yogjakarta: CV. Andi Offset

16. Zaduqisti. (2009). Stereotipe peran gender bagi pendidikan anak. Jurnal Muwazah Vol.1, No.1, 2009. 